SOURCES OF ECONOMIC HOPE: WOMEN'S ENTREPRENEURSHIP

November 2014

Ewing Marion

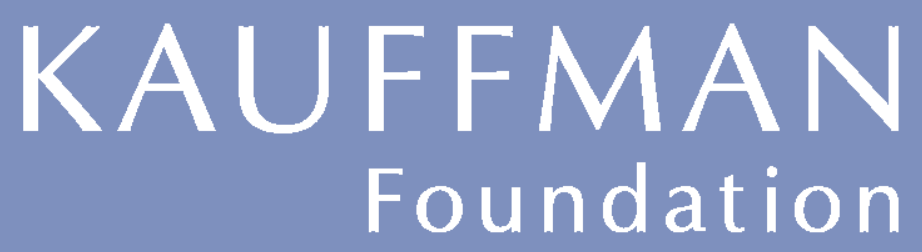




\title{
SOURCES OF ECONOMIC HOPE: WOMEN'S ENTREPRENEURSHIP
}

\author{
November 2014
}

\author{
Alicia Robb \\ Ewing Marion Kauffman Foundation \\ Susan Coleman \\ University of Hartford \\ Dane Stangler \\ Ewing Marion Kauffman Foundation
}

Ewing Marion

\author{
KAUFFMAN \\ Foundation
}

The authors would like to acknowledge Neesha Bapat; Samantha Huang; Kristen Van Nest; Vivek Wadhwa; the Arthur and Toni Rembe Rock Center for Corporate Governance, Stanford University; the Pratt School of Engineering, Duke University; and Shaherose Charania - Women 2.0 for their contributions, and Leslie Cintron and Joanne Cohoon from the University of Virginia for advising. 


\section{SOURCES OF ECONOMIC HOPE: WOMEN'S ENTREPRENEURSHIP}

In 1948, the gap in labor force participation between American men and women was 54 percentage points-only one-third of American women were officially counted as in the labor force. Nearly seven decades later, the gap has narrowed considerably as women have entered the labor force en masse, and as men have experienced steady declines. As of August 2014, about 57 percent of women were counted as labor force participants, and the gap between men and women had narrowed to only 13 percentage points.

Meanwhile, women have made remarkable educational gains over the last few decades. Women now consistently outpace men in terms of college enrollment and receive 50 percent more master's degrees than men do. Among the youngest workers, those eighteen to thirty-two, women are now far more likely to have bachelor's degrees than men are.

These concurrent trends-the large-scale entry of women into the official labor force and rising educational attainment, especially among women-served as huge economic tailwinds for the U.S. economy during the twentieth century. In fact, they were so important that a slowdown in such trends is now counted as a major reason for pessimism about the future of American economic growth.

Economist Robert Gordon, for example, sees the growth in women's labor force participation as a one-time development unlikely to be repeated or replicated. ${ }^{1}$ Even though women are only at 57 percent labor force participation currently, the room for growth is smaller now than it was before, and the trend has slowed. Likewise, the rise in schooling for both women and men can continue for some time, but short of sending everyone to post-graduate school, some think we've reached a point of slowing, if not diminishing, returns.

These are two reasons why rampant pessimism is now afoot about America's long-term growth prospects. In a cover story this past summer, The Economist called it "America's lost oomph." While short-term growth seems to have recovered to pre-recession rates, the permanent damage wrought by the Great Recession may have knocked the United States to lower potential GDP for a long time to come. ${ }^{2}$ Continuous revisions have been made to long-term forecasts, with most observers now putting the United States at around 2 percent annual economic growth for the coming decades. That compares to 3 percent annual growth during the last 100 years.

Everyone, then, is in search of those future economic tailwinds or "shocks" that will give a boost to twenty-first-century growth in the same way that women's labor force entry

\footnotetext{
${ }^{1}$ Gordon, Robert J., "Is U.S. Economic Growth Over? Faltering Innovation Confronts the Six Headwinds," NBER Working Paper, August 2012 at http://www.nber.org/papers/w18315.

2 O'Brien, Matt, "This is why the economy has fallen and it can't get up," The Washington Post Wonkblog, October 31, 2014 at http://www.washingtonpost.com/blogs/wonkblog/wp/2014/10/31/this-is-why-theeconomy-has-fallen-and-it-cant-get-up/.
} 
and rising educational attainment did during the twentieth century. One potential boost is a crucial economic area where women continue to be underrepresented: entrepreneurship, especially high-growth entrepreneurship.

Overall, women-owned businesses account for about one-third of all types of businesses in the United States. Among employer firms, however, women-owned businesses are only about 16 percent of the total, and their share of revenues and employees are in the single digits. Among high-growth firms, moreover, women usually account for less than 10 percent of founders in any given sample.

These types of statistics, however, aren't necessarily the right kind of frame for approaching the issue. The matter of women and entrepreneurship is not one of trying to reach some sort of quota; it also is not a matter of "fixing" women or "fixing" entrepreneurship or "fixing" anything else. This is an economic growth issue, and to the extent that half of the American population and more than half of our educated population are not fully participating in the engine of growth and innovation, it is an opportunity to avoid the "secular stagnation" that is now expected for the American economy.

Despite fervent levels of interest in entrepreneurship around the country, official rates of business creation have been falling for a number of years and have yet to recover from their recessionary nadir. It's possible that a rebound is already underway, that the explosion of entrepreneurship education and training programs soon will pay off in the form of more new businesses. It's also possible that the participation of women in entrepreneurial activity and high-growth entrepreneurship is in reversal. Many programs specifically targeting women have been formed the past few years, and their impact may be taking shape around us.

Either way, given the slowing rates of business creation, the long-term pessimism about growth in the United States, and the rising share of women among educated workers, it seems clear that the future of American entrepreneurship and growth is in the hands of women. We need to figure out what will help the country take advantage of this opportunity.

One way to do this is to identify what might be contributing to the low percentage of women represented among high-growth companies and the investors who back them. What, if anything, is different among women entrepreneurs, and what does this tell us about public policy and private programs?

Some researchers attribute women's lower levels of participation in growth-oriented entrepreneurship to gender differences in key resource inputs in human, social, and financial capital (Carter et al., 1997; Coleman, 2007; Fairlie \& Robb, 2009; Menzies, et al., 2004; Orser, et al., 2006; Robb \& Wolken, 2002). An increasing number of studies have examined access to capital as a possible impediment to the growth of womenowned firms (Brush et al., 2001; Brush, et al., 2004; Coleman \& Robb, 2009). Recent studies indicate that women-owned entrepreneurs raise smaller amounts of capital to 
finance their firms and are more reliant on personal rather than external sources of financing (Coleman \& Robb, 2009; Coleman \& Robb, 2010). Within the context of growth-oriented entrepreneurship, this distinction is important, because growth-oriented firms typically require substantial amounts of external capital in both debt and equity. If women entrepreneurs do not seek, or if they are not able to obtain, external capital, their prospects for growing their firms are diminished considerably.

We investigated these issues in more detail through a survey, conducted by Vivek Wadhwa and with the support of the Arthur and Toni Rembe Rock Center for Corporate Governance, Stanford University; the Pratt School of Engineering, Duke University; and Women 2.0, of women who were founding CEOs, presidents, chief technology officers, or leading technologists of tech startups founded between 2002 and 2012. Here, we present some results from nearly 350 responses, comparing them to the sample of high-tech firms tracked in the Kauffman Firm Survey (KFS), a longitudinal survey of firms that began operations in 2004.

More than one-third of the firms surveyed began operations in 2012, while about 40 percent began in 2010 or 2011 (Table 1). Less than 10 percent began in the pre-crisis years of 2002-2007, while about 14 percent were started during the height of the financial crisis in 2008 and 2009.

While the survey focused on tech firms, these firms came from a wide distribution of industries. About 17 percent of the firms were in retail and e-commerce, while another 15 percent were in health care, wellness, and medicine. About 14 percent of firms were in community, social networking, and collaboration industries, while about 11 percent were in industries related to education, recruitment, and jobs. Just fewer than 9 percent of firms were in advertising or marketing. The remaining industries had 5 percent or less of the firms in the survey: audio, visual, and media (5.2 percent), energy, environment, and sustainability (3.4 percent), gaming and virtual worlds ( 3 percent), and finance and payments (2.3 percent).

Survey findings highlight three primary challenges for women-owned high-tech firms:

- Lack of mentors. Surprisingly few women in the survey cited a role model as their motivation for starting a business - and lack of available advisors is cited as one of their top challenges. More access to mentors is an important strategy for encouraging women to start and run successful high-growth companies.

- Their view of success and failure. Women entrepreneurs rank lessons from failures higher on their list of factors contributing to success than lessons from successes.

- A financing gap. A high fraction of these survey respondents cited financial capital as a critical challenge to launching their firms (72.1 percent), and the majority (nearly 80 percent) used personal savings as their top funding source. This was surprising, given that about 31 percent of these respondents used 
angel investors and 14 percent had venture capital financing, much higher levels than businesses more generally and even high-tech firms, specifically. Building the financial capabilities of women and ensuring access to outside financing is among the recommendations we list in the following report.

Recent studies suggest that women entrepreneurs are making gains in fields previously dominated by men (National Women's Business Council 2012 Annual Report), but there is still a significant gap in fields such as information technology, manufacturing, construction, and transportation (Hackler et al., 2008; Developments in Women-owned Business, 1997-2007, 2011). These gaps are important to understand because these industries provide fertile ground for both revenue generation and employment opportunities.

\section{SURVEY FINDINGS: SMALL FIRM SIZE}

The vast majority of firms surveyed were small. Nearly a third had no employees other than the business owner herself. More than 56 percent had one to five employees, while 8 percent had six to ten. Only about 6 percent had more than ten employees, with just 1 percent having more than fifty employees.

\begin{tabular}{|c|c|}
\hline \multicolumn{2}{|l|}{ Year Founded } \\
\hline $2002-2006$ & 4.65 \\
\hline 2007 & 4.07 \\
\hline 2008 & 4.36 \\
\hline 2009 & 9.3 \\
\hline 2010 & 12.79 \\
\hline 2011 & 27.62 \\
\hline 2012 & 37.21 \\
\hline \multicolumn{2}{|l|}{ Industry } \\
\hline Advertising and Marketing & 8.67 \\
\hline Audio, Visual, and Media & 5.2 \\
\hline Communities, Social Networking \& Collab. & 13.87 \\
\hline Education, Recruitment, and Jobs & 10.98 \\
\hline Energy, Environment, Sustainability, & 3.47 \\
\hline Enterprise: Security, Storage, and Collab. & 10.4 \\
\hline Finance and Payments & 2.31 \\
\hline Gaming, Virtual Worlds & 2.89 \\
\hline Health Care, Medicine, and Wellness & 15.03 \\
\hline Retail, Shopping, and Ecommerce & 16.76 \\
\hline Travel and Transport & 3.47 \\
\hline Other & 6.94 \\
\hline \multicolumn{2}{|l|}{ Number of Full Time Employes } \\
\hline Yourself Only & 29.15 \\
\hline 1 to 5 & 56.56 \\
\hline 6 to 10 & 8.16 \\
\hline 11 to 50 & 4.96 \\
\hline $51+$ & 1.16 \\
\hline
\end{tabular}

Source: Survey of founding CEOs, Presidents, CTOs, or lead technologists of tech startups founded between 2002 and 2012 


\section{CHARACTERISTICS OF FEMALE ENTREPRENEURS}

The women surveyed for this report were extremely well educated. Table 2 illustrates this in detail. More than 56 percent had graduate degrees, while nearly 40 percent had bachelor's degrees. Only about 5 percent of respondents had associates degrees or less. As shown in Appendix 2, women founders of high-tech firms from the Kauffman Firm Survey also were well educated, but not to the same extent as the group highlighted in this study. The KFS shows 23 percent of women having graduate degrees and 45 percent having bachelor's degrees, while nearly one-third (32 percent) had some college or less. Business was the field of study most cited by the women surveyed (27 percent), followed by Liberal Arts (20 percent), and Computer Science, Engineering, and IT (18 percent).

In terms of entrepreneurial pursuits, nearly 20 percent of the survey respondents indicated that they were under the age of twenty-five when they started their first company, while another quarter was between the ages of twenty-five and twenty-nine. A full one-third of respondents were in their thirties and the remaining $20+$ percent were aged forty and above.

Table 2: Distribution of Firms by Founder Characteristics

\begin{tabular}{|c|c|}
\hline \multicolumn{2}{|l|}{ Education Level } \\
\hline Associate Degree or Less & 5.23 \\
\hline Bachelorís Degree & 38.95 \\
\hline Master's Degree & 47.68 \\
\hline Doctoral Degree & 8.14 \\
\hline \multicolumn{2}{|l|}{ In What Field was Your Highest Degree? } \\
\hline Business & 27.46 \\
\hline Liberal Arts & 19.94 \\
\hline Computer Science/IT/Engineering & 18.21 \\
\hline Social Sciences & 9.83 \\
\hline Design & 4.91 \\
\hline Natural Sciences & 4.62 \\
\hline Law & 3.47 \\
\hline Education & 2.89 \\
\hline Behavioral Sciences & 2.6 \\
\hline Other & 2.31 \\
\hline Medicine & 1.73 \\
\hline Mathematics & 0.87 \\
\hline \multicolumn{2}{|l|}{ Age When You Founded Your First Company } \\
\hline$<20$ & 4.64 \\
\hline $20-24$ & 15.11 \\
\hline $25-29$ & 25.29 \\
\hline $30-39$ & 33.42 \\
\hline $40-49$ & 16.85 \\
\hline $50+$ & 4.64 \\
\hline
\end{tabular}

Source: Survey of founding CEOs, Presidents, CTOs, or lead technologists of tech startups founded between 2002 and 2012 


\section{FOUNDER DRIVERS}

Respondents were asked about their motivations for starting a company or getting involved in an early-stage firm. In other research literature, important motivations for growth-oriented entrepreneurs, whether male or female, have been things like the potential for financial gain, the desire to work for oneself, and the drive to pursue an idea. The tech entrepreneurs in this survey were no different from most other surveys of entrepreneurs. (See Table 3.)

If we aggregate responses in terms of extremely important, very important, and important, respondents cited the following three factors: wanting to capitalize on a business idea (85.6 percent), the startup company culture appealed to them (75.8 percent), and they have always wanted to start their own business (72.6 percent). Two-thirds of respondents ranked the following two factors as important, very important, or extremely important: working for someone else didn't appeal to them and to build wealth.

These findings generally accord with other survey findings about what motivates entrepreneurs and to what degree. One interesting thing to note about these responses is that a surprisingly low percentage of women cited a role model as their motivation for entering entrepreneurship. Women entrepreneurs who have successfully grown their firms also can have an impact by serving as role models and mentors for other women contemplating entrepreneurship or attempting to launch their businesses. Mentorship is very important for successful entrepreneurs and, while this sample was very limited, this finding potentially could indicate one reason behind the low share of women in growth entrepreneurship.

A much smaller fraction of respondents indicated that their development of a technology that they wanted to make into a business venture was what motivated them ( $<10$ percent) or that a co-founder encouraged them to become a business partner in starting a company (6 percent). Less than 3 percent said that not being able to find traditional employment was a motivating factor. 


\begin{tabular}{|c|c|c|c|c|c|c|c|c|c|}
\hline \multicolumn{10}{|c|}{ able 3: Motivations for Starting Your Business } \\
\hline & $\begin{array}{l}\text { Couldn't } \\
\text { find } \\
\text { traditional } \\
\text { employ- } \\
\text { ment }\end{array}$ & $\begin{array}{l}\text { Working } \\
\text { for } \\
\text { someone } \\
\text { else } \\
\text { didn't } \\
\text { appeal to } \\
\text { me }\end{array}$ & $\begin{array}{l}\text { Wanted } \\
\text { to build } \\
\text { wealth }\end{array}$ & $\begin{array}{l}\text { Co-founder } \\
\text { encouraged } \\
\text { me to } \\
\text { become a } \\
\text { business } \\
\text { partner and } \\
\text { start a } \\
\text { company }\end{array}$ & $\begin{array}{l}\text { Wanted to } \\
\text { capitalize on } \\
\text { a business } \\
\text { idea that I } \\
\text { had }\end{array}$ & $\begin{array}{l}\text { Developed a } \\
\text { technology } \\
\text { in a lab and } \\
\text { wanted to } \\
\text { make it into } \\
\text { a business }\end{array}$ & $\begin{array}{l}\text { Startup } \\
\text { company } \\
\text { culture } \\
\text { appealed } \\
\text { to me }\end{array}$ & $\begin{array}{l}\text { Have } \\
\text { always } \\
\text { wanted to } \\
\text { own my } \\
\text { own } \\
\text { company }\end{array}$ & $\begin{array}{l}\text { An } \\
\text { entrepreneu } \\
\text { rial friend/ } \\
\text { family } \\
\text { member was } \\
\text { a role model }\end{array}$ \\
\hline Extremely important & $2.9 \%$ & $24.3 \%$ & $22.4 \%$ & $6.1 \%$ & $52.7 \%$ & $9.3 \%$ & $33.4 \%$ & $40.1 \%$ & $18.4 \%$ \\
\hline Very important & $2.9 \%$ & $22.4 \%$ & $22.4 \%$ & $11.9 \%$ & $19.5 \%$ & $5.8 \%$ & $23.6 \%$ & $16.2 \%$ & $11.1 \%$ \\
\hline Important & $5.1 \%$ & $19.5 \%$ & $23.6 \%$ & $9.6 \%$ & $13.4 \%$ & $5.1 \%$ & $18.8 \%$ & $16.2 \%$ & $19.0 \%$ \\
\hline Slightly important & $7.0 \%$ & $17.9 \%$ & $22.4 \%$ & $9.6 \%$ & $8.0 \%$ & $5.8 \%$ & $13.7 \%$ & $10.5 \%$ & $14.8 \%$ \\
\hline Not at all important & $65.5 \%$ & $13.1 \%$ & $8.3 \%$ & $28.5 \%$ & $4.5 \%$ & $31.7 \%$ & $8.3 \%$ & $11.5 \%$ & $22.3 \%$ \\
\hline N/A & $16.6 \%$ & $2.9 \%$ & $1.0 \%$ & $34.3 \%$ & $1.9 \%$ & $42.3 \%$ & $2.2 \%$ & $5.4 \%$ & $14.4 \%$ \\
\hline Total & $100 \%$ & $100 \%$ & $100 \%$ & $100 \%$ & $100 \%$ & $100 \%$ & $100 \%$ & $100 \%$ & $100 \%$ \\
\hline $\begin{array}{l}\text { Cited as Important, } \\
\text { Very Important, or } \\
\text { Extremely Important }\end{array}$ & $10.9 \%$ & $66.1 \%$ & $68.4 \%$ & $27.6 \%$ & $85.6 \%$ & $20.2 \%$ & $75.8 \%$ & $72.6 \%$ & $48.5 \%$ \\
\hline
\end{tabular}

Note: Survey question was: How important were the following in motivating you to start your business?

Source: Survey of founding CEOs, Presidents, CTOs, or lead technologists of tech startups founded between 2002 and 2012

\section{SUCCESS FACTORS}

Survey respondents also were asked about their perceptions of what had contributed to their success in starting and building companies. As shown in Table 4, the highestranking factor was prior industry experience, followed by two sources of learning: lessons from previous successes and lessons from previous failures. Interestingly, a higher proportion of women cited lessons learned from previous failures as "extremely important" (44.1 percent) than lessons learned from previous successes (37.4 percent). Also near the top in terms of self-identified drives of success were professional business networks and the company's management team.

Very few respondents ranked advice/assistance from investors (8.7 percent) or from state/regional agencies (4.1 percent) as extremely important for their success. 


\begin{tabular}{|c|c|c|c|c|c|c|c|c|c|c|c|}
\hline \multicolumn{12}{|c|}{ Table 4: Drivers of Success } \\
\hline & $\begin{array}{l}\text { Your } \\
\text { university } \\
\text { education }\end{array}$ & $\begin{array}{l}\text { Your prior } \\
\text { industry } \\
\text { work } \\
\text { experience }\end{array}$ & $\begin{array}{l}\text { Lessons } \\
\text { learned } \\
\text { from } \\
\text { previous } \\
\text { successes }\end{array}$ & $\begin{array}{l}\text { Lessons } \\
\text { learned } \\
\text { from } \\
\text { previous } \\
\text { failures }\end{array}$ & $\begin{array}{l}\text { Company's } \\
\text { management } \\
\text { team }\end{array}$ & $\begin{array}{l}\text { Availability } \\
\text { of financial } \\
\text { capital }\end{array}$ & $\begin{array}{l}\text { Advice/ } \\
\text { assistance } \\
\text { provided by } \\
\text { company } \\
\text { investors }\end{array}$ & Location & $\begin{array}{l}\text { Assistance } \\
\text { provided by } \\
\text { state/ } \\
\text { regional } \\
\text { agencies }\end{array}$ & $\begin{array}{l}\text { University } \\
\text { alumni } \\
\text { contacts/ } \\
\text { networks }\end{array}$ & $\begin{array}{l}\text { Professional } \\
\text { business } \\
\text { networks }\end{array}$ \\
\hline Extremely important & $20.7 \%$ & $45.7 \%$ & $37.4 \%$ & $44.1 \%$ & $30.1 \%$ & $21.2 \%$ & $8.7 \%$ & $12.8 \%$ & $4.1 \%$ & $15.0 \%$ & $39.9 \%$ \\
\hline Very important & $21.1 \%$ & $23.3 \%$ & $29.1 \%$ & $25.7 \%$ & $24.1 \%$ & $20.5 \%$ & $13.2 \%$ & $18.8 \%$ & $4.8 \%$ & $15.0 \%$ & $24.3 \%$ \\
\hline Important & $26.3 \%$ & $19.2 \%$ & $21.7 \%$ & $17.5 \%$ & $19.6 \%$ & $22.4 \%$ & $19.9 \%$ & $23.3 \%$ & $9.8 \%$ & $14.6 \%$ & $18.5 \%$ \\
\hline Slightly important & $16.1 \%$ & $5.4 \%$ & $5.8 \%$ & $5.7 \%$ & $6.6 \%$ & $14.1 \%$ & $15.8 \%$ & $15.7 \%$ & $9.8 \%$ & $16.2 \%$ & $6.7 \%$ \\
\hline Not at all important & $14.1 \%$ & $4.2 \%$ & $1.6 \%$ & $1.6 \%$ & $6.0 \%$ & $9.3 \%$ & $12.9 \%$ & $19.5 \%$ & $40.3 \%$ & $25.5 \%$ & $6.7 \%$ \\
\hline N/A & $1.6 \%$ & $2.2 \%$ & $4.5 \%$ & $5.4 \%$ & $13.6 \%$ & $12.5 \%$ & $29.6 \%$ & $9.9 \%$ & $31.1 \%$ & $13.7 \%$ & $3.8 \%$ \\
\hline Total & $100 \%$ & $100 \%$ & $100 \%$ & $100 \%$ & $100 \%$ & $100 \%$ & $100 \%$ & $100 \%$ & $100 \%$ & $100 \%$ & $100 \%$ \\
\hline $\begin{array}{l}\text { Total citing Important } \\
\text { Very Important, or } \\
\text { Extremely Important }\end{array}$ & $68.1 \%$ & $88.2 \%$ & $88.2 \%$ & $87.3 \%$ & $73.7 \%$ & $64.1 \%$ & $41.8 \%$ & $55.0 \%$ & $18.7 \%$ & $44.6 \%$ & $82.7 \%$ \\
\hline
\end{tabular}

Note: Survey question was: How important were the following in the success of your most recent startup?

Source: Survey of founding CEOs, Presidents, СTOs, or lead technologists of tech startups founded between 2002 and 2012

Again, these findings would not seem to differ substantially from both male and female entrepreneurs. In his study of high-growth firms in the 1980s and 1990s, Amar Bhide found that most of the founders had some form of prior industry experience that informed their entrepreneurial ventures. ${ }^{3}$ But an interesting wrinkle emerges when we compare these survey findings to previous ones about the incidence and experience of failure among women and men entrepreneurs.

A 2010 innovation survey in the United States sponsored by UNCTAD focused on gender differences. One interesting finding from those data was that women business owners had fewer failure experiences than men, which may suggest that women are more likely to take calculated risks and develop contingency plans if events do not transpire as anticipated (Coleman \& Robb, 2012; Coleman \& Robb 2014). Women and men business owners in the sample also exhibited different responses to failure experiences. Whereas both women and men responded that their own hard work was the major factor in recovering from a failure (43.9 percent and 37.9 percent), men were much more likely to attribute their recovery to self-confidence than women were (33.3 percent vs. 17.5 percent). Women were more willing than men were to turn to external advisors (7.9 percent vs. 4.5 percent) to help them recover from failure experiences.

\section{FUNDING TOPS CHALLENGES}

No matter what type of business they're in, no matter their gender, and no matter their age, entrepreneurs of all kinds face challenges in starting and growing companies. Not surprisingly, the types of challenges they face tend to be similar. Entrepreneurship is hard, and the respondents to this survey agreed.

\footnotetext{
${ }^{3}$ Amar Bhide, The Origin and Evolution of New Businesses (Oxford, 2000).
} 
In terms of challenges respondents faced with their business ventures, the three factors most frequently cited as somewhat of a challenge, a big challenge, or extremely challenging: amount of time and effort required (76.9 percent), lack of availability of financial capital (72.1 percent), and lack of available mentors or advisors (47.9 percent). As shown in Table 5, the other factors were cited by about 35 percent to 45 percent of respondents each: difficulty with co-founder recruitment, protecting company's intellectual capital, consequences of failure, health insurance, lack of prior experience running a business, lack of industry knowledge, and family or financial pressures to keep a traditional job.

Table 5: Challenges in Starting Your Business

\begin{tabular}{|c|c|c|c|c|c|c|c|c|c|c|}
\hline & $\begin{array}{l}\text { Amount } \\
\text { of time } \\
\text { and effort } f \\
\text { required }\end{array}$ & $\begin{array}{l}\text { Difficulty } \\
\text { with co- } \\
\text { founder } \\
\text { recruitment }\end{array}$ & $\begin{array}{l}\text { Concern } \\
\text { about } \\
\text { protecting } \\
\text { company's } \\
\text { intellectual } \\
\text { capital }\end{array}$ & $\begin{array}{l}\text { Lack of } \\
\text { availability } \\
\text { of financial } \\
\text { capital }\end{array}$ & $\begin{array}{l}\text { Concern about } \\
\text { the } \\
\text { consequences } \\
\text { of failure }\end{array}$ & $\begin{array}{l}\text { Availability } \\
\text { of health } \\
\text { insurance, } \\
\text { risk of losing } \\
\text { existing } \\
\text { coverage }\end{array}$ & $\begin{array}{l}\text { Lack of } \\
\text { prior } \\
\text { experience } \\
\text { running a } \\
\text { business }\end{array}$ & $\begin{array}{l}\text { Lack of } \\
\text { industry } \\
\text { knowledge }\end{array}$ & $\begin{array}{l}\text { Family or } \\
\text { financial } \\
\text { pressures to } \\
\text { keep a } \\
\text { traditional, } \\
\text { steady job }\end{array}$ & $\begin{array}{l}\text { Lack of } \\
\text { available } \\
\text { mentors } \\
\text { or } \\
\text { advisors }\end{array}$ \\
\hline Extremely challenging & $23.1 \%$ & $15.8 \%$ & $6.7 \%$ & $30.8 \%$ & $9.9 \%$ & $12.0 \%$ & $5.7 \%$ & $2.9 \%$ & $9.5 \%$ & $11.8 \%$ \\
\hline A big challenge & $29.1 \%$ & $12.0 \%$ & $8.6 \%$ & $17.8 \%$ & $13.4 \%$ & $12.3 \%$ & $13.0 \%$ & $9.6 \%$ & $14.0 \%$ & $14.1 \%$ \\
\hline Somewhat of a challenge & $24.7 \%$ & $10.4 \%$ & $29.1 \%$ & $23.5 \%$ & $20.4 \%$ & $12.6 \%$ & $24.4 \%$ & $21.5 \%$ & $14.0 \%$ & $22.0 \%$ \\
\hline A small challenge & $13.3 \%$ & $12.0 \%$ & $27.5 \%$ & $14.9 \%$ & $33.5 \%$ & $20.2 \%$ & $24.8 \%$ & $22.8 \%$ & $19.7 \%$ & $16.0 \%$ \\
\hline Not at all a challenge & $9.2 \%$ & $33.9 \%$ & $24.3 \%$ & $7.6 \%$ & $21.4 \%$ & $30.6 \%$ & $23.8 \%$ & $36.9 \%$ & $35.2 \%$ & $33.2 \%$ \\
\hline N/A & $0.6 \%$ & $15.8 \%$ & $3.8 \%$ & $5.4 \%$ & $1.3 \%$ & $12.3 \%$ & $8.3 \%$ & $6.4 \%$ & $7.6 \%$ & $2.9 \%$ \\
\hline Total & $100 \%$ & $100 \%$ & $100 \%$ & $100 \%$ & $100 \%$ & $100 \%$ & $100 \%$ & $100 \%$ & $100 \%$ & $100 \%$ \\
\hline
\end{tabular}

Percentage citing

Somewhat of a Challenge,

a Big Challenge, or

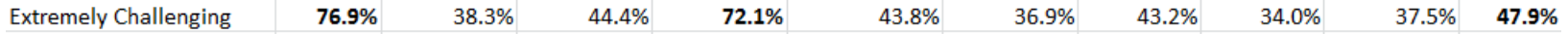

Note: Survey question was: How much of a challenge have the following been for you in starting your business?

Source: Survey of founding CEOs, Presidents, CTOs, or lead technologists of tech startups founded between 2002 and 2012

Lack of accessibility to financial capital was cited by nearly 31 percent as extremely challenging, and cited by nearly 18 percent as a big challenge. Almost a quarter said it was somewhat of a challenge, while 15 percent said it was a small challenge. Only 7.6 percent said it was not a challenge at all.

Research continues to find that women entrepreneurs borrow smaller amounts than men do across all industries, including high tech (Coleman \& Robb forthcoming; Coleman \& Robb, 2009; Haynes \& Haynes, 1999). An even more significant gap between women and men persists when it comes to securing sources of equity capital in the form of angel investments, venture capital, or private equity (Brush et al., 2004; Harrison \& Mason, 2007; Robb, 2013). This is not necessarily a problem for smaller firms, which tend to rely on internal sources of capital and external debt in the form of bank loans. Nevertheless, accessing sufficient amounts of external equity capital is a major impediment for women entrepreneurs who launch growth-oriented firms.

A recent survey in the first quarter of 2014 of Inc. 500|5000 firms showed just how different financing strategies are for female founders and male founders of these highgrowth firms. Male founders were more than three times as likely as female founders to 
access equity financing through angels or VCs (14.4 percent versus 3.6 percent). Men also were more likely than women were to tap networks of close friends (9.2 percent versus 1.8 percent) and business acquaintances (13.5 percent versus 5.4 percent). More than half of each (51.3 percent of men and 55.4 percent of women) used bank financing as a source of capital for their Inc. 5000 firms (Coleman and Robb, forthcoming).

A recent study by Coleman and Robb (forthcoming) using the Kauffman Firm Survey found that, overall, men start firms with nearly twice the capital that women do. These discrepancies, which actually widen at the higher end of firm size spectrum, have implications for the growth trajectories of firms and appear to be one driver of the relatively smaller sizes of women-owned firms. The top-ranking female businesses in the KFS by employment (Top 25) and those that had high growth potential (HGP) with women-owned firms overall reveal some striking differences. In terms of financing, both Top 25 and HGP women-owned firms in general started with much more capital than firms overall did. Nevertheless, these women-owned firms started with dramatically lower levels of capital than did their male owned Top 25 and HGP counterparts. Similarly, growth-oriented women-owned firms used higher levels of outside equity, but again, much less than their male-owned counterparts. Multivariate analyses revealed that women were injecting significantly lower levels of financial capital and outside equity into their firms in multiple years, even after controlling for credit risk, industry, and a variety of other factors that influence the demand (and supply) of credit (Coleman and Robb, forthcoming).

In terms of sources of funds used by the businesses in this paper's survey, nearly 80 percent of respondents said they used personal savings (Table 6). About 31 percent used angel investors, while about half that (14 percent) had venture capital financing. About 20 percent of respondents were able to use business partners as a source of funds, while only 5 percent to 6 percent each used bank loans, government/foundation grants, and business revenues. A very small percentage used corporate investors (1.7 percent), accelerators (1.5 percent), or crowdfunding (1.2 percent).

This is clearly not representative of businesses more generally, nor of high-tech firms specifically. A much higher percentage of these respondents rely on outside equity financing than firms more generally do. Thus, it is interesting to note that such a high fraction of these respondents also cited the issue of financial capital as a critical challenge to launching their firms. Nearly one-third of the firms in the sample were currently trying to raise funds.

Since financing is one of the key inputs and resources required by a growth-oriented firm, this financing gap is clearly related to the size gap between men- and womenowned businesses. Growth-oriented firms generate jobs and economic impact, and female entrepreneurs are markedly unrepresented in this subset of firms. It is estimated that only about 2 percent of women-owned firms generate more than a million dollars, and there are less than one million women-owned firms in the entire country that have any employees other than the owner herself. These are striking statistics that suggest 
women entrepreneurs represent a large and untapped resource for generating jobs and high-growth businesses.

Table 6: Funding Patterns

\begin{tabular}{l|r|r|}
\hline What are Your Main Sources of Funding? (select all that apply) & \\
\hline Personal Savings & 272 & $79.1 \%$ \\
\hline Angel Investors & 106 & $30.8 \%$ \\
\hline Friends and Family & 104 & $30.2 \%$ \\
\hline Business Partners & 70 & $20.3 \%$ \\
\hline Venture Capital & 48 & $14.0 \%$ \\
\hline Bank Loans & 20 & $5.8 \%$ \\
\hline Government Program/Foundation Grants & 18 & $5.2 \%$ \\
\hline Business Revenues & 17 & $4.9 \%$ \\
\hline Bootstrapping & 14 & $4.1 \%$ \\
\hline Corporate Investors & 6 & $1.7 \%$ \\
\hline Accelerators & 5 & $1.5 \%$ \\
\hline Crowdfunding & 4 & $1.2 \%$ \\
\hline Other & 4 & $1.2 \%$ \\
\hline Have You Raised Capital for Your Company from VCs or Angels & \\
\hline & & Percent \\
\hline No, I have not raised capital for my company & 122 & 35.47 \\
\hline No, but I'm currently trying to raise capital & 110 & 31.98 \\
\hline Yes & 112 & 32.56 \\
\hline Total & 344 & 100 \\
\hline
\end{tabular}

Source: Survey of founding CEOs, Presidents, CTOs, or lead technologists of tech startups founded between 2002 and 2012

\section{RECOMMENDATIONS}

The overall thrust of the survey findings presented here and their comparison with prior research, especially analysis of high-tech firms in the Kauffman Firm Survey sample, is that female and male entrepreneurs have a lot in common. They would seem to start their companies for similar reasons, cite similar self-perceived reasons for success, and face similar challenges. Out of this similarity, three differences do stand out.

First, the women technology entrepreneurs surveyed here don't appear to have had inspiring role models as their principal motivation. Second, women entrepreneurs in general appear to respond differently than men do to failure, and cite lessons learned from failure as a big reason for success. Finally, there is a financing gap when it comes to high-tech and high-potential women entrepreneurs. That financing gap turns into a growth gap in terms of company outcomes. Findings ways to fill that financing gap, then, could have huge payoff in job creation and innovation.

What, if anything, can government and other organizations do to capitalize on the growth opportunity that exists with women entrepreneurs? 
First, building the financial capabilities of women and ensuring access to bank financing and equity financing by venture capitalists and angel investors is paramount to having more high-growth entrepreneurship by women. Second, encouraging greater participation by women on the financing and investing side also might be an avenue worth pursuing. Prior research documents the low level of representation of women as investors in angel investing and venture capital funds. A growing number of angel groups, such as Golden Seeds, Astia Angels, and the Pipeline Fellowship, are preparing women to become investors in this space. More is needed to overcome the gender imbalance on the funding side.

Other steps also can be taken to support high-growth women's entrepreneurship in ways that will allow us to tap this greatly underutilized resource. This issue needs to be addressed on multiple fronts: 1) by offering more opportunities in industry that will give women the experience needed to pursue entrepreneurship, 2) by providing more opportunities to learn about starting and growing businesses, and 3) through exposure to successful female entrepreneurs who can share stories and insights from their successes (and challenges). Family-friendly policies that allow women the flexibility to work outside of their homes and schedule activities around family commitments might also encourage women to tackle higher-growth opportunities.

A recent paper from the Office of Advocacy at the Small Business Administration (SBA), found that different university programs, even those within the same field, can provide different types of exposure among men and women to entrepreneurial opportunity. ${ }^{4}$ In fields such as mechanical engineering, where women represent a small share of graduate students, male and female students still have different experiences when it comes to their faculty advisors, interaction with private industry, and entrepreneurship. Given how important prior exposure (whether in industry or in entrepreneurship) was for survey respondents here, finding a way to address the differential structure of these programs could put more women onto the high-growth entrepreneurial pathway.

Encouraging and facilitating team startups (men, women, and mixed) is another avenue to pursue, given that our findings highlight the importance of team ownership in securing financial capital, particularly during the critical early years of the firm. There are an increasing number of organizations and events such as Startup Weekend Women's Edition, Startup Grind, Founder Fridays, and Co-Founder speed dating that serve as encouraging examples of ways to meet this need.

Programs that specifically target women-owned, high-growth-potential firms also have shown considerable success. Astia and Springboard Enterprises are two programs that have built successful track records in helping scale women-owned companies by providing them access to equity financing, as well as business mentorship and training. Clearly, more of these types of programs are needed if we are going to truly move the needle on high-growth women's entrepreneurship.

\footnotetext{
${ }^{4}$ Blume-Kohout, Margaret E., "Understanding the Gender Gap in STEM Fields Entrepreneurship," Office of Advocacy, Small Business Administration, October 2014, at http://www.sba.gov/sites/default/files/Gender\%20Gap\%20in\%20STEM\%20Fields.pdf.
} 


\section{APPENDIX 1}

Primary Owner Characteristics of Technology-Based Firms from the KFS

Owner Age

Years of Previous Industry Work Experience

Previous Startup Experience

Number of Previous Startups

Average Hours Worked (week)

Education Level

High School Graduate or Less

Some College

College Degree

Post-Grad Education

$\mathrm{N}$

Focus of Highest Degree

Science

Technical

Business

Liberal Arts

Other

$\mathrm{N}$

*** $p<0.01,{ }^{* *} p<0.05,{ }^{*} p<0.1$
All: 2004

Female Male

$44.9 \quad 44.8$

$11.8 \quad 16.5$

$36.3 \% \quad 50.0 \%$ *

$0.649 \quad 1.281 \quad$ **

$38.9 \quad 42.8$

$3.2 \% \quad 3.6 \%$

$28.7 \% \quad 26.8 \%$

$45.4 \% \quad 36.2 \%$

$22.7 \% \quad 33.4 \%$

80

446

Surviving Firms:

2008

Female Male

$38.7 \% \quad 42.8 \%$

$19.3 \% \quad 14.8 \%$

$24.7 \% \quad 22.7 \%$

$11.7 \% \quad 18.4 \%$

$5.6 \% \quad 1.2 \%$

$55 \quad 305$

Source: Kauffman Firm Survey Microdata. Sample includes only surviving firms over the period 2004-2008 and those that have been verified as going out of business over the same period. 


\section{APPENDIX 2}

Capital Structure of New Technology-Based Firms

Initial Startup Capital and New Financial Injections-KFS

\begin{tabular}{|c|c|c|c|c|c|}
\hline \multirow{3}{*}{$\begin{array}{l}\text { Startup Capital } \\
\text { Owner Equity }\end{array}$} & \multicolumn{5}{|c|}{ All Firms: 2004} \\
\hline & Female & Male & & Female & Male \\
\hline & $\$ 20,967$ & $\$ 31,857$ & & $32.2 \%$ & $20.4 \%$ \\
\hline Insider Equity & $\$ 1,993$ & $\$ 2,482$ & & $3.1 \%$ & $1.6 \%$ \\
\hline Outsider Equity & $\$ 2,654$ & $\$ 74,004$ & ** & $4.1 \%$ & $47.3 \%$ \\
\hline Owner Debt & $\$ 5,558$ & $\$ 6,871$ & & $8.5 \%$ & $4.4 \%$ \\
\hline Insider Debt & $\$ 2,699$ & $\$ 4,292$ & & $4.1 \%$ & $2.7 \%$ \\
\hline Outsider Debt & $\$ 31,317$ & $\$ 36,981$ & & $48.0 \%$ & $23.6 \%$ \\
\hline Total Financial & $\$ 65,187$ & $\$ 156,486$ & $* *$ & $100.0 \%$ & $100.0 \%$ \\
\hline
\end{tabular}

Average Annual New Injections (20052008)

$\begin{array}{llllll} & \text { Female } & \text { Male } & & \text { Female } & \text { Male } \\ \text { Owner Equity } & \$ 6,768 & \$ 33,896 & * * & 11.3 \% & 19.8 \% \\ \text { Insider Equity } & \$ 545 & \$ 3,996 & & 0.9 \% & 2.3 \% \\ \text { Outsider Equity } & \$ 16,999 & \$ 77,893 & & 28.4 \% & 45.5 \% \\ \text { Owner Debt } & \$ 7,396 & \$ 5,581 & & 12.4 \% & 3.3 \% \\ \text { Insider Debt } & \$ 2,624 & \$ 6,088 & & 4.4 \% & 3.6 \% \\ \text { Outsider Debt } & \$ 25,477 & \$ 43,872 & * * & 42.6 \% & 25.6 \% \\ \text { Total Financial } & \$ 59,809 & \$ 171,326 & * * & 100.0 \% & 100.0 \% \\ * * * & p<0.01,{ }^{* *} p<0.05,{ }^{*} p<0.1 & & & & \end{array}$

Source: Kauffman Firm Survey Microdata. Sample includes only surviving firms over the period 2004-2008 and those that have been verified as going out of business over the same period.

Women-owned firms represent an important segment of the business sector. According to estimates using the latest available data from the U.S. Census Bureau, there were nearly 9 million privately-held women-owned firms in the United States in 2012 (U.S. Census Bureau 2012). As shown in Appendix 3, these firms generated an estimated $\$ 1.4$ trillion in sales and employed 7.8 million people. Women-owned firms continue to comprise a minority of all firms (30 percent) and they continue to generate much smaller shares of revenues (3.8 percent), employment (6.2 percent), and payroll (4.3 percent). While their share in terms of the number of businesses continues to grow over time, their shares of employer firms, revenues, employment, and payroll have stagnated or even declined over the last two decades. In light of the gains women have made in education and in the labor market, their level of growth-oriented entrepreneurship actually should be much higher. 


\section{APPENDIX 3: WOMEN-OWNED BUSINESSES}

\begin{tabular}{|c|c|c|c|c|}
\hline Women-Owned Firms & 1997 & 2002 & 2007 & 2012 \\
\hline Firms (number) & $5,417,034$ & $6,489,483$ & $7,793,425$ & $8,943,038$ \\
\hline Receipts (millions of & & & & \\
\hline dollars) & $\$ 818,669$ & $\$ 940,775$ & $\$ 1,192,781$ & $\$ 1,358,187$ \\
\hline Employer Firms (number) & 846,780 & 916,768 & 911,285 & 956,116 \\
\hline $\begin{array}{l}\text { Receipts (millions of } \\
\text { dollars) }\end{array}$ & $\$ 717,764$ & $\$ 804,097$ & $\$ 1,010,470$ & $\$ 1,136,816$ \\
\hline Employees (number) & $7,076,081$ & $7,146,229$ & $7,587,020$ & $7,780,716$ \\
\hline $\begin{array}{l}\text { Annual Payroll (millions } \\
\text { of dollars) }\end{array}$ & $\$ 149,116$ & $\$ 173,709$ & $\$ 218,136$ & $\$ 249,340$ \\
\hline \multicolumn{5}{|l|}{ All Firms } \\
\hline Firms (number) & $20,821,934$ & $22,974,685$ & $27,110,362$ & $29,924,088$ \\
\hline $\begin{array}{l}\text { Receipts (millions of } \\
\text { dollars) }\end{array}$ & $\$ 18,553,243$ & $\$ 22,627,167$ & $\$ 30,181,461$ & $\$ 35,415,508$ \\
\hline Employer Firms (number) & $5,295,151$ & $5,524,813$ & $5,752,975$ & $5,982,137$ \\
\hline $\begin{array}{l}\text { Receipts (millions of } \\
\text { dollars) }\end{array}$ & $\$ 17,907,940$ & $\$ 21,859,758$ & $\$ 29,208,766$ & $\$ 34,292,981$ \\
\hline Employees (number) & $103,359,815$ & $110,786,416$ & $118,668,699$ & $126,247,194$ \\
\hline $\begin{array}{l}\text { Annual Payroll (millions } \\
\text { of dollars) }\end{array}$ & $\$ 2,936,493$ & $\$ 3,813,488$ & $\$ 4,886,977$ & $\$ 5,829,470$ \\
\hline \multicolumn{5}{|l|}{$\begin{array}{l}\text { Women-Owned Firms as a } \\
\text { Percentage of All }\end{array}$} \\
\hline Firms & $26.0 \%$ & $28.2 \%$ & $28.7 \%$ & $29.9 \%$ \\
\hline Receipts & $4.4 \%$ & $4.2 \%$ & $4.0 \%$ & $3.8 \%$ \\
\hline $\begin{array}{l}\text { Employer Firms } \\
\text { Receipts of Employer }\end{array}$ & $16.0 \%$ & $16.6 \%$ & $15.8 \%$ & $16.0 \%$ \\
\hline Firms & $4.0 \%$ & $3.7 \%$ & $3.5 \%$ & $3.3 \%$ \\
\hline Employees & $6.8 \%$ & $6.5 \%$ & $6.4 \%$ & $6.2 \%$ \\
\hline Annual Payroll & $5.1 \%$ & $4.6 \%$ & $4.5 \%$ & $4.3 \%$ \\
\hline
\end{tabular}

Source: 1997, 2002, and 2007 Surveys of Business Owners and Author Calculations 